\title{
Teaching Features and Improvement Suggestions for Chinese Online Classes
}

\author{
Yidan Kong \\ Shanghai International Studies University, Shanghai, China
}

\begin{abstract}
The popularity of the Internet has influenced education profoundly. Teaching methods, teacher-student relationships, and the role of teachers have changed significantly due to changes in communication media. In the case of Chinese language learning, online classes have become a crucial tool to encourage and support international Chinese teaching. With the deepening of China's opening, exchanges between China and other countries are becoming increasingly profound. Against this backdrop, worldwide enthusiasm for learning Chinese has emerged, yet not every foreign learner of Chinese has had the opportunity to attend Chinese lessons and receive systemic training. To give more students the opportunity to study Chinese, online lessons are a viable option for various reasons, from acting as an effective channel for students to learn about both Chinese language and culture to offering classes of both short and long duration, and providing a range of different teaching styles and teaching methods depending on the needs of the students. This paper analyzes teachers and methods after observing many Chinese online teaching videos that have attracted a high "click rate" by users. Moreover, this paper focuses on analyzing MOOC and traditional online lessons published by the Confucius Institute and carries out a comparison between them and overseas online Chinese lessons. Finally, this paper evaluates online Chinese lessons and gives suggestions according to the $5 \mathrm{C}$ goals of language teaching.
\end{abstract}

Index Terms - Chinese teaching, the internet, teachers, teaching methods, $5 \mathrm{C}$

\section{INTRODUCTION}

Chinese is gaining popularity around the world. By the end of 2020, there were 1170 Confucius Classes and 541 Confucius Institutes in 162 countries around the world, according to the Confucius Institute's statistics. (1) Despite this, Chinese teaching resources overseas are still very scarce. Therefore, the Internet has rapidly become a significantly important tool, and even the preferred choice for some overseas learners, due to its ability to be accessible to an enormous number of learners, its convenience and the low costs associated with online learning compared to some traditional learning methods.

Although the history of teaching Chinese as a foreign language is not particularly extensive, it also has followed the development path of other foreign language teachings. Up to now, with the prevalence of functionalism and interaction theory, most teachers have adopted functional, interactive, and task-based methods in Chinese classes (Everson M.\& Xiao Y. 2009). However, due to reasons such as students not being located in a Chinese-speaking environment and having low levels of interaction with teachers, different types of online teaching methods have resulted.

\section{The Overview OF ONLINE Overseas Chinese Classes}

To undertake this research, YouTube, the biggest global video website was selected as the data source. After searching for the phrase learn Chinese on YouTube, the results showed that there were 17 Chinese teaching videos with more than 1 million views respectively and 4 channels with more than 10, 0000 subscribers. The following 4 channels were selected: Chinesepod, Learn Chinese with ChineseClass101.com, Learn Chinese Now and Learn Chinese with Emma. Moreover, YouTube displayed 20 videos on the topic of greetings which were all beginner Chinese lessons that had relatively high numbers of viewers; these videos have also been analyzed in this research. Various elements of the abovementioned YouTube videos have been the focus of this study, namely, the length of the videos, their number of views, the background of teachers (i.e., whether the teacher comes from an official organization or is a private teacher), each teacher's nationality, the language of instruction, the language of courseware, and the main topics covered in each video.

\section{A. The Form of Foreign Online Chinese Classes}

Based on the researcher's observations, none of the most viewed and most highly subscribed Chinese teaching videos and channels on YouTube can be considered as traditional classroom teaching videos. Instead, they are all short videos recorded by teachers. As such, it can be said that this form is relatively popular and in high demand in the market for Chinese learners.

\footnotetext{
${ }^{1}$ Data sourc : ehttp://www.hanban.edu.cn/confuciousinstitutes/node_10961.htm
} 
By analyzing the 20 most popular videos that range from 3 minutes to 25 minutes in length, it is found that the number of viewers decreases rapidly for videos longer than 20 minutes. This tendency means that in the current information era, people tend to use the fragmented time for learning. Table 1 below shows a comparison of the main features of the form of the videos.

TABLE I.

THE Form FEATURES OF CHINESE TEACHING VIDEOS ON YOUTUBE

\begin{tabular}{|c|c|c|c|c|c|c|c|c|c|c|}
\hline & $\begin{array}{l}\text { Name of } \\
\text { Channels }\end{array}$ & $\begin{array}{l}\text { Leng } \\
\text { th }\end{array}$ & Views & $\begin{array}{r}\text { Praise } \\
\text { Rate }\end{array}$ & $\begin{array}{l}\text { The } \\
\text { Background } \\
\text { of Teachers }\end{array}$ & $\begin{array}{l}\text { Teachers' } \\
\text { Nationali } \\
\text { ty }\end{array}$ & $\begin{array}{l}\text { The } \\
\text { Number } \\
\text { s of } \\
\text { Teachers }\end{array}$ & $\begin{array}{l}\text { Language } \\
\text { of } \\
\text { Instruction }\end{array}$ & $\begin{array}{l}\text { Coursew } \\
\text { are's } \\
\text { Languag } \\
\text { es }\end{array}$ & $\begin{array}{l}\text { Teaching } \\
\text { Focuses }\end{array}$ \\
\hline 3 & $\begin{array}{l}\text { Learn } \\
\text { Chinese with } \\
\text { Emma }\end{array}$ & $3^{\prime} 26^{\prime}$ & $\begin{array}{l}3,167,83 \\
7\end{array}$ & $\begin{array}{l}97.5 \\
\%\end{array}$ & Private & $\begin{array}{l}\text { Ethnic } \\
\text { Chinese }\end{array}$ & 1 & $\begin{array}{l}\text { English } \\
\text { (main); } \\
\text { Chinese } \\
\text { (compleme } \\
\text { ntary) }\end{array}$ & $\begin{array}{l}\text { Chinese } \\
\text { (words); } \\
\text { English } \\
\text { (meanin } \\
\text { g) }\end{array}$ & $\begin{array}{l}\text { Pronunci } \\
\text { ation; } \\
\text { Meaning }\end{array}$ \\
\hline 4 & $\begin{array}{l}\text { Mandarin } \\
\text { Impossible }\end{array}$ & $\begin{array}{l}17 ' 1 \\
6{ }^{\prime},\end{array}$ & 343,022 & $97 \%$ & Private & $\begin{array}{l}\text { Ethnic } \\
\text { Chinese }\end{array}$ & 1 & $\begin{array}{l}\text { English, } \\
\text { expect } \\
\text { reading } \\
\text { words in } \\
\text { Chinese. }\end{array}$ & $\begin{array}{l}\text { Chinese } \\
\text { (words); } \\
\text { English } \\
\text { (meanin } \\
\text { g) }\end{array}$ & $\begin{array}{l}\text { Pronunci } \\
\text { ation; } \\
\text { Meaning }\end{array}$ \\
\hline 5 & CultureAlley & $\begin{array}{l}16^{\prime} 1 \\
2^{\prime \prime}\end{array}$ & 50,078 & $\begin{array}{l}93.2 \\
\%\end{array}$ & $\begin{array}{l}\text { CultureAlle } \\
\text { y Company }\end{array}$ & Western & 1 & $\begin{array}{l}\text { English, } \\
\text { expect } \\
\text { reading } \\
\text { words in } \\
\text { Chinese. }\end{array}$ & $\begin{array}{l}\text { Chinese } \\
\text { (words); } \\
\text { English } \\
\text { (meanin } \\
\text { g) }\end{array}$ & $\begin{array}{l}\text { Pronunci } \\
\text { ation; } \\
\text { Meaning }\end{array}$ \\
\hline 6 & CultureAlley & $\begin{array}{l}21 ' 3 \\
4{ }^{\prime \prime}\end{array}$ & 68,659 & $\begin{array}{l}93.6 \\
\%\end{array}$ & $\begin{array}{l}\text { CultureAlle } \\
\text { y Company }\end{array}$ & Western & 1 & $\begin{array}{l}\text { English, } \\
\text { expect } \\
\text { reading } \\
\text { words in } \\
\text { Chinese. }\end{array}$ & $\begin{array}{l}\text { Chinese } \\
\text { Pinyin } \\
\text { (words); } \\
\text { English } \\
\text { (meanin } \\
\text { g) }\end{array}$ & $\begin{array}{l}\text { Pronunci } \\
\text { ation; } \\
\text { Meaning }\end{array}$ \\
\hline 8 & $\begin{array}{l}\text { EverydayChi } \\
\text { nese - Learn } \\
\text { Chinese in } \\
\text { Chinatown }\end{array}$ & $2^{\prime} 52^{\prime}$ & 2,716 & $97 \%$ & $\begin{array}{l}\text { Everyday } \\
\text { Chinese } \\
\text { Company }\end{array}$ & Chinese & 1 & $\begin{array}{l}\text { English, } \\
\text { expect } \\
\text { reading } \\
\text { words in } \\
\text { Chinese. }\end{array}$ & $\begin{array}{l}\text { Chinese } \\
\text { Pinyin } \\
\text { (words); } \\
\text { English } \\
\text { (meanin } \\
\text { g) } \\
\end{array}$ & $\begin{array}{l}\text { Pronunci } \\
\text { ation; } \\
\text { Meaning; } \\
\text { Usage }\end{array}$ \\
\hline 9 & Chinesepod & $2^{\prime} 33^{\prime}$ & 7,358 & $98 \%$ & $\begin{array}{l}\text { Chinesepod } \\
\text { Company }\end{array}$ & $\begin{array}{l}\text { Chinese, } \\
\text { North } \\
\text { America, } \\
\text { Europe }\end{array}$ & $1-2$ & $\begin{array}{l}\text { English } \\
\text { (main); } \\
\text { Chinese } \\
\text { (compleme } \\
\text { ntary) }\end{array}$ & $\begin{array}{l}\text { Chinese } \\
\text { (words); } \\
\text { English } \\
\text { (meanin } \\
\text { g) }\end{array}$ & $\begin{array}{l}\text { Pronunci } \\
\text { ation; } \\
\text { Usage }\end{array}$ \\
\hline 10 & $\begin{array}{l}\text { ChineseCorne } \\
\mathrm{r}\end{array}$ & $\begin{array}{l}14 ' 5 \\
9{ }^{\prime}\end{array}$ & 11,874 & $\begin{array}{l}92.9 \\
\%\end{array}$ & Private & Canada & $\begin{array}{l}1 \\
\text { (teachin } \\
\text { g);10 } \\
\text { (acting } \\
\text { in } \\
\text { context) }\end{array}$ & $\begin{array}{l}\text { English } \\
\text { (main); } \\
\text { Chinese } \\
\text { (compleme } \\
\text { ntary) }\end{array}$ & $\begin{array}{l}\text { Chinese } \\
\text { (words); } \\
\text { English } \\
\text { (meanin } \\
\text { g) }\end{array}$ & $\begin{array}{l}\text { Pronunci } \\
\text { ation; } \\
\text { Meaning; } \\
\text { Usage; } \\
\text { Pragmati } \\
\text { c } \\
\text { Function }\end{array}$ \\
\hline 11 & $\begin{array}{l}\text { eChineseLear } \\
\text { ning }\end{array}$ & 3'19' & 3,597 & $\begin{array}{l}89.7 \\
\%\end{array}$ & $\begin{array}{l}\text { eChineseLe } \\
\text { arning } \\
\text { Company }\end{array}$ & $\begin{array}{l}\text { Ethnic } \\
\text { Chinese }\end{array}$ & 1 & $\begin{array}{l}\text { English } \\
\text { (main); } \\
\text { Chinese } \\
\text { (compleme } \\
\text { ntary) }\end{array}$ & $\begin{array}{l}\text { Chinese } \\
\text { (words); } \\
\text { English } \\
\text { (meanin } \\
\text { g) }\end{array}$ & $\begin{array}{l}\text { Meaning; } \\
\text { Usage }\end{array}$ \\
\hline
\end{tabular}




\begin{tabular}{|c|c|c|c|c|c|c|c|c|c|c|}
\hline & & & & & & & & $\begin{array}{l}\text { (compleme } \\
\text { ntary) }\end{array}$ & $\begin{array}{l}\text { Pinyin } \\
\text { English } \\
\text { (meanin } \\
\text { g) }\end{array}$ & \\
\hline 13 & $\begin{array}{l}\text { Learn } \\
\text { Chinese Now }\end{array}$ & $1^{\prime \prime} 21^{\prime}$ & 105,619 & $\begin{array}{l}98.7 \\
\%\end{array}$ & Private & $\begin{array}{l}\text { North } \\
\text { America } \\
\text { 、 Ethnic } \\
\text { Chinese }\end{array}$ & 2 & $\begin{array}{l}\text { English, } \\
\text { expect } \\
\text { reading } \\
\text { words in } \\
\text { Chinese. }\end{array}$ & $\begin{array}{l}\text { Chinese } \\
\text { (words); } \\
\text { Chinese } \\
\text { Pinyin } \\
\text { English } \\
\text { (meanin } \\
\text { g) }\end{array}$ & $\begin{array}{l}\text { Pronunci } \\
\text { ation; } \\
\text { Meaning }\end{array}$ \\
\hline 14 & $\begin{array}{l}\text { Fluent in } \\
\text { Mandarin.co } \\
\mathrm{m}\end{array}$ & $\begin{array}{l}4^{\prime} 10^{\prime} \\
\end{array}$ & 2,359 & $98 \%$ & Private & $\begin{array}{l}\text { North } \\
\text { America }\end{array}$ & 1 & $\begin{array}{l}\text { English, } \\
\text { expect } \\
\text { reading } \\
\text { words in } \\
\text { Chinese. }\end{array}$ & $\begin{array}{l}\text { Chinese } \\
\text { (words); } \\
\text { Chinese } \\
\text { Pinyin } \\
\text { English } \\
\text { (meanin } \\
\text { g) }\end{array}$ & $\begin{array}{l}\text { Pronunci } \\
\text { ation; } \\
\text { Meaning }\end{array}$ \\
\hline 15 & $\begin{array}{l}\text { Fluent in } \\
\text { Mandarin.co } \\
\mathrm{m}\end{array}$ & $6^{\prime} 09^{\prime}$ & 2,968 & $98 \%$ & Private & $\begin{array}{l}\text { North } \\
\text { America }\end{array}$ & 1 & $\begin{array}{l}\text { English, } \\
\text { expect } \\
\text { reading } \\
\text { words in } \\
\text { Chinese. }\end{array}$ & $\begin{array}{l}\text { Chinese } \\
\text { (words); } \\
\text { Chinese } \\
\text { Pinyin } \\
\text { English } \\
\text { (meanin } \\
\text { g) } \\
\end{array}$ & $\begin{array}{l}\text { Pronunci } \\
\text { ation; } \\
\text { Meaning }\end{array}$ \\
\hline 16 & $\begin{array}{l}\text { PeggyTeaches } \\
\text { Chinese }\end{array}$ & $3 ’ 02$ & 39,122 & $\begin{array}{l}97.4 \\
\%\end{array}$ & Private & $\begin{array}{l}\text { Ethnic } \\
\text { Chinese }\end{array}$ & 1 & $\begin{array}{l}\text { English, } \\
\text { expect } \\
\text { reading } \\
\text { words in } \\
\text { Chinese. }\end{array}$ & $\begin{array}{l}\text { Chinese } \\
\text { Pinyin } \\
\text { English } \\
\text { (meanin } \\
\text { g) }\end{array}$ & $\begin{array}{l}\text { Pronunci } \\
\text { ation; } \\
\text { Meaning }\end{array}$ \\
\hline 17 & $\begin{array}{l}\text { SEEMILE } \\
\text { Chinese }\end{array}$ & $5^{\prime} 58^{\prime}$ & 154,461 & $\begin{array}{l}96.6 \\
\%\end{array}$ & $\begin{array}{l}\text { SEEMILE } \\
\text { Company }\end{array}$ & $\begin{array}{l}\text { South } \\
\text { Korea }\end{array}$ & 1 & $\begin{array}{l}\text { English, } \\
\text { expect } \\
\text { reading } \\
\text { words in } \\
\text { Chinese. }\end{array}$ & $\begin{array}{l}\text { Chinese } \\
\text { Chinese } \\
\text { Pinyin }\end{array}$ & $\begin{array}{l}\text { Pronunci } \\
\text { ation; } \\
\text { Meaning }\end{array}$ \\
\hline 18 & Askbenny & $\begin{array}{l}4^{\prime} 03^{\prime} \\
x^{\prime}\end{array}$ & 11,432 & $\begin{array}{l}96.7 \\
\%\end{array}$ & Private & Chinese & 1 & $\begin{array}{l}\text { English, } \\
\text { expect } \\
\text { reading } \\
\text { words in } \\
\text { Chinese. }\end{array}$ & $\begin{array}{l}\text { Chinese } \\
\text { (words); } \\
\text { Chinese } \\
\text { Pinyin } \\
\text { English } \\
\text { (meanin } \\
\text { g) }\end{array}$ & $\begin{array}{l}\text { Pronunci } \\
\text { ation; } \\
\text { Meaning }\end{array}$ \\
\hline 19 & $\begin{array}{l}\text { Learn } \\
\text { Chinese with } \\
\text { Yi Zhao }\end{array}$ & $3^{\prime} 49^{\prime}$ & 19,972 & $\begin{array}{l}97.4 \\
\%\end{array}$ & Private & Chinese & 1 & $\begin{array}{l}\text { English, } \\
\text { expect } \\
\text { reading } \\
\text { words in } \\
\text { Chinese. }\end{array}$ & $\begin{array}{l}\text { Chinese } \\
\text { (words); } \\
\text { Chinese } \\
\text { Pinyin } \\
\text { English } \\
\text { (meanin } \\
\text { g) }\end{array}$ & $\begin{array}{l}\text { Pronunci } \\
\text { ation; } \\
\text { Meaning }\end{array}$ \\
\hline 20 & $\begin{array}{l}\text { Paloma } \\
\text { Renee ASMR } \\
\text { (ASMR } \\
\text { Teaching You } \\
\text { Chinese) }\end{array}$ & $\begin{array}{l}13{ }^{\prime} 1 \\
5 "\end{array}$ & 4,461 & $98 \%$ & Private & Europe & 1 & $\begin{array}{l}\text { English, } \\
\text { expect } \\
\text { reading } \\
\text { words in } \\
\text { Chinese. }\end{array}$ & $\begin{array}{l}\text { Chinese } \\
\text { (words); } \\
\text { Chinese } \\
\text { Pinyin } \\
\text { English } \\
\text { (meanin } \\
\text { g) }\end{array}$ & $\begin{array}{l}\text { Pronunci } \\
\text { ation; } \\
\text { Meaning }\end{array}$ \\
\hline
\end{tabular}

\section{B. Teaching Features of Online Overseas Chinese Classes}

The history of teaching Chinese as a foreign language began with the admission of the first group of foreign students in 1950, however, Zhao Jinming regarded a statement by Zhao Yuanren in 1925 as the beginning of it. Zhao Yuanren pointed out in Phonograph Course in Chinese National Language that "teaching languages with gramophone records is not novel, and it is not the first-time teaching Chinese with it, but it is the first attempt teaching Chinese to foreigners with it." (Zhao Jinming, 2010). Over nearly a century, rapid progress has been made in teaching Chinese as a foreign language, accompanied by an evolution from the grammar-translation method to interactive methods and task-based methods, among others. However, due to reasons such as learners having a lack of context and there being either a delay in communication or complete lack of actual interaction between teachers and learners, two significant differences between overseas online Chinese classes and traditional Chinese international education classes have emerged; one being the language of instruction and the other being teaching methods.

First, online Chinese classes aimed at students located outside of China are taught mainly by teachers who use the students' own mother tongue. For example, English is commonly used as the medium of instruction to teach Chinese to overseas students. Accordingly, Chinese is merely adopted when students need to practice pronouncing characters, 
which often severely limits the ability for students to have a high intake of Chinese and is obviously very different from offsetting used in a traditional Chinese language class. In contrast, the Chinese Ministry of Education has underlined on multiple occasions the importance of using the target language (i.e., Chinese) during classes, as opposed to the students' native tongue (Zhao Jinming, 2020).

Second, from functionalism and interactive theory it can be seen in the comments of various scholars that there should be an emphasis on context and usage in language teaching. In their opinion, language is the most crucial interactive tool. The functional method, interactive method and task-based method have become mainstream for teaching Chinese as a foreign language in China. This type of teaching method has as its goal the development of students' communicative competence in the target language, and the teaching materials are developed in terms of communicative tasks rather than there being an overwhelming focus on grammar. Furthermore, classes should simulate an authentic communicative environment as much as possible, and the teaching process should emphasize student-centeredness, with the teacher playing a supportive role and emphasizing oral expression rather than linguistic forms. Finally, in this type of environment, teachers are encouraged to tolerate students' errors to a high degree so as not to negatively influence students' confidence or the flow of the learning experience.

However, few overseas online Chinese classes have applied functionalism theories in teaching due to there being a delay in the communication between teachers and students as well as an overall lack of interaction in such classes. If teachers adopt the target language and interactive method during distance education for an extended period, it may be the case that learners give up because they cannot understand the content of the teacher's classes. Therefore, the student audience is a pivotal factor that dictates how online classes will be structured and to what degree they will differ from traditional Chinese lessons.

\section{The Analysis of Teaching Methods of Overseas Online Chinese Classes}

Because of the features of the Internet, most overseas online Chinese classes adopt a method that combines grammar-translation with the audiolingual method. The grammar-translation method is the oldest method in foreign language teaching, using the students' native language as the language of instruction to translate the focus points of the target language, focusing on written language and grammar, and using the classical works of authors as the main source of teaching materials (White, L. 2003). The translation method does not focus on assisting students with their listening or speaking skills. The psychological foundation of the audiolingual method is the stimulus-response theory of behavioristic psychology (Mcloughlin, L. \& Lertola, J. 2014). According to this theory, if the stimulus and training are strong enough, students can master the target language. This theory focuses heavily on listening and speaking at the expense of reading and writing.

As previously mentioned, most online Chinese classes adopt a method that combines the grammar-translation method with the audiolingual method. In terms of its main features, teachers use their own or the learners' native language to translate words and sentences taught in the target language. Taking greetings as an example, teachers would translate the Chinese phrase Zao3 Shang4hao3 word by word as "good morning". In some videos, when teaching Chinese greetings, teachers tend to split up Chinese words and translate them in English, for instance, splitting the Chinese expression Ni3 hao3 into Ni3 and hao3, and then translating them as "you" "good", or splitting Bu2 cuo4 into Bu2 and cuo4, and then translating them into "not" "bad". Secondly, most videos involve teachers explaining the meaning of Chinese words and teaching the correct pronunciation, with the aim of having students repeat the words several times to practice their pronunciation. Thirdly, teachers do not spend a lot of time on the usage and interactive function for individual words. Taking Chinese greetings again as an example, many videos tell students that greeting words should be used in the first sentence when two or more people meet. However, very few videos would acknowledge and demonstrate to students that there can be both formal and informal meetings between people, requiring different types of greetings depending on the degree of formality. There is only one video on Chinesepod further subdividing the context of Chinese greetings into general communication, acquaintances' communication, and chums' communication. Moreover, except for some simple greeting phrases, such as Ni3 hao3 ("hello"), Zao3 anl and Zao3 Shang4hao3 ("good morning"), this video also explains some common Chinese greetings. However, the interactive function is not employed as the teacher simply translates them word by word, such as Chil le1ma? (Have you eaten?), Ni3 Qu4 na3'er le1? (Where have you been?). Fourthly, in regards to tone, some videos focus on the different tones in Chinese to help students with their speaking skills. However, overall, there is not a great deal of focus on tonal changes; only one video points out that the total value of Ni3 in Ni3 hao3 goes from Ni3 to Ni2. We can conclude that the content for beginner Chinese classes on the Internet is mainly on the topic of greetings. Moreover, due to the lack of actual communication and interaction between teachers and learners, such videos usually involve using the native language as the medium of instruction and employing the grammar-translation method. Such videos highlight the importance of listening and speaking, which is different from the grammar-translation method and closer to the audiolingual method that excludes the learners' first language.

\section{Similarities AND DifferenCES BETWEEN OVERSEAS ONLINE CHINESE LESSONS AND MOOC OF THE CONFUCIUS} INSTITUTE 


\section{A. Similarities between Overseas Online Chinese Lessons and the MOOC of the Confucius Institute}

Online lessons provided by the Confucius Institute can be divided into two parts: MOOC and traditional online lessons, the former is the abbreviation of Massive Open Online Course and its rapid development is based on the proliferation of websites and mobile intelligence technologies. MOOC underlines the interaction between teachers and learners, and learners' subjectivity. The latter has most of the features of traditional classes, except that the location is shifted from offline to online. The teaching methods are mainly the expository method, leading students to read aloud, and so on. Some videos just play the recording of offline lessons. Besides, with the popularization of the Internet, there are some other forms of online Chinese teaching, for example, micro-lesson and flipped classes, the former of which are mainly short teaching videos to meet learners' requirements for mobile and fragmented learning. The common feature of these online teaching formats is that they reach a large target audience with people from diverse backgrounds. Another feature of online classes is that they are open, especially MOOC. Their teaching methods, resources, evaluation and other processes are all open to learners, in accordance with the 4Rs open-frame construction (reuse, revise, remix, re-distribute) proposed by Stephen Dansky (Liang Lin, 2016).

\section{B. Differences between Overseas Online Chinese Lessons and MOOC of Confucius Institute}

\section{Interactivity}

Overseas online Chinese classes are less interactive than MOOC of Confucius Institute, as students can only leave comments to the video publisher at the bottom of YouTube videos or subscribed channels, and a Chinese teaching channel is often operated by a company or an institution. Therefore, the creator of the video, the teacher and the publisher are never the same person, which results in there being a delay and lack of interaction between teachers and learners. In contrast, the MOOC of the Confucius Institute has its own online community that can let teachers communicate with learners or learners exchange with each other. However, despite the online community of the MOOC of the Confucius Institute is more interactive than Chinese teaching channels on YouTube, teachers are still not enthusiastic about mentoring. The lack of interaction is not the focus of this paper, so it will not be discussed below.

\section{Languages Used in Classes}

The language used in the MOOC of the Confucius Institute is mainly Mandarin Chinese, which encourages an immersive learning experience for students and strives to create a real language environment for them. Most of the highly popular Chinese teaching videos on the Internet use students' mother tongue as the language of instruction. Chinese is only used when demonstrating how to pronounce new words. Thus, such a learning environment does not guarantee the significant input of Chinese for learners. At the primary stage of learning a language the learner will only have limited knowledge of Chinese, and so the students' native language can be useful as it helps them ease anxiety. However, excessive use of their first language can make students dependent on it and reduce the likelihood of them resorting to using Chinese and dampen their motivation to practice.

\section{Systematic and Individualized}

Most of the Confucius Institute's MOOC are taught in a series of lessons on a single topic. Each lesson tends to cover one to two language points, with after-class assignments to help learners understand and consolidate what they have learnt. According to students' country of origin, age, interests and purpose for learning Chinese, courses on MOOC have been divided into six categories: language course, literature, history and philosophy course, culture course, special-purpose course, special instructional media and pedagogy course, Chinese teacher training course, which are suitable for students of different stages and levels. Compared with this, most overseas online Chinese lessons are not structured in a systematic way and instead, students merely learn the language in a disconnected manner without any sense of order. Moreover, overseas online Chinese lessons are typically divided lessons very broadly into beginner, intermediate and advanced, and do not further classify videos in any other way. This can create problems as it does not consider learners' individual circumstances.

\section{Cultural Property and Pragmatic Knowledge}

Chinese language learning is not just about mastering a communicative tool. Chinese contains rich traditional culture; if one person does not understand the culture then he/she cannot master the language. In addition, pragmatic knowledge is another important aspect of language learning. Pragmatic knowledge includes the context, emotional overtones, associative meaning, and stylistic differences of a linguistic form. MOOC of Confucius Institute has a specialized cultural lesson that introduces and explains Chinese culture, but there are only a few lessons that combine language and culture. Learners, in order to truly grasp Chinese culture, may need to take additional lessons on culture. Furthermore, linguistic lessons lack enough guidance in terms of pragmatics and genre. Overseas online Chinese videos rarely refer to cultural knowledge and do not cover pragmatics or genre.

\section{Teaching Methods}

The MOOC of the Confucius Institute is relatively flexible in terms of its various teaching methods, such as the grammar-translation method, read-aloud training, questioning method, display (pictures and material objects) method, and the audiolingual method, etc. They also assign some homework, for example, letting learners finish interactive tasks (communicative method, task-based method). Most overseas online videos just adopt one or two methods, mainly using the grammar-translation method or read-aloud training for listening and speaking, which may be repetitive for students and not result in them being enthusiastic about learning Chinese. 


\section{Main Issues of Overseas OnLine Confucius InStitute}

The convenience, efficiency, ability to target a broad target audience and cost-effectiveness of the Internet are some of the main reasons why methods of teaching have drastically changed, thereby promoting the teaching of Chinese language and culture. However, online teaching is still in its infancy in many respects and this next section outlines some of the ways that it can be improved.

Firstly, there is clearly a lack of sufficient professional Chinese teachers. Chinese learning videos that have been clicked more than 50,000 times on YouTube include teachers who are either individual freelance teachers or who are from training agencies, neither of which have received systematic training on how to teach Chinese as a foreign language. As a result, such teachers may lack comprehensive knowledge of the overall Chinese language system and moreover, do not employ effective methods of teaching. One common problem from such videos is that they rarely explain the reasons behind a linguistic phenomenon. Therefore, it can be hard for students to understand complexities in the language, and instead, teachers rely on merely teaching idiomatic usages or fixed expressions, without providing any greater background context. In addition, these videos are often not designed in any systematic order, that is, complex content may be taught at an early stage, while fundamental knowledge is taught later, disrupting the students' ability to absorb information that is suited to their level of Chinese. Finally, some teachers do not speak using standard pronunciation, which can easily affect students' ability to speak standard Mandarin Chinese using the correct tones.

Secondly, the length of the videos is often too short. Most of the Chinese videos ranked in the top 20 are less than 25 minutes in length, and some of them are even less than 5 minutes. In this era of information, people's attention span has become shorter and shorter, and short videos are beneficial to learning at fragmented spare time. However, due to the lack of professional teachers and systematic structure of the learning process, and the fragmented learning time, the learning effect is not ideal and usually gets half the result with twice the effort. Due to limitations of time and budget, most of them choose to learn online. The lack of context on daily life is another reason why they cannot get an ideal learning effect.

Finally, there is a deficiency in pragmatics, genre, cultural knowledge. These Chinese teaching videos simply explain Chinese greetings on a basic level in order to allow learners to roughly master Chinese greetings in the shortest possible time. However, there are all kinds of factors in a truly interactive scenario that would perhaps impact the appropriate type of greeting that needs to be used by the speaker. In fact, learners using such videos may find that in many cases, what they have learnt cannot be applied in an actual typical Chinese conversation.

\section{RECOMMENDATIONS FOR IMPROVEMENT OF OVERSEAS ONLINE CHINESE LESSONS AND ONLINE LESSONS OF CONFUCIUS INSTITUTE}

\section{A. Recommendations for Improvement on Overseas Online Chinese Lessons}

The standards of the new century proposed by Standards for Foreign Language Learning in the $21^{\text {st }}$ Century are Communication, Cultures, Connections, Comparisons and Communities (Lin Liang, 2016, p.81). Comparisons refer to the comparison between the learners' first language and the target language, involving both language and culture. Its purposes are to know and understand the features of the target language, cultural beliefs associated with the language and the complex relationship between language and culture.

1. The Perspective of Communication in $5 C$

The standard of Communication is that learners do not simply need to be limited to acquiring language knowledge but can also learn to express their own opinions and feelings in the target language. To enable this outcome, teachers are required to have a relatively high level of understanding of pragmatic and knowledge of the genre. With such skills, these teachers will be able to provide context to learners when teaching different words and phrases and will be able to describe to learners which kind of genre is appropriate. Teachers would then not need to merely focus on pronunciation, words, and grammar, but allow students the opportunity to express themselves in Chinese in a more authentic way, mimicking the language habits of native Chinese speakers.

2. The Perspective of Cultures and Comparisons in $5 C$

Persons who create videos that are used to teach Chinese should pay particular attention to how they can embed their videos with aspects of Chinese culture. In this way, Chinese language does not need to be taught in a "vacuum" context, but rather, the fundamental aspects of Chinese culture can be taught throughout each video, in a way that does not make the video particularly long, but instead enhances the overall educational quality of the video. This is especially important for language learners of Chinese who have little to no access to understand Chinese culture in their own communities. To assist such learners of Chinese, comparisons can be made, highlighting similarities and differences, between the students' own culture and Chinese culture.

3. The Perspective of Communities in $5 \mathrm{C}$

Persons in charge of Chinese teaching channels should assign a particular person to take charge of collating messages that are posted by viewers of the videos. By implementing this process, creators of the videos can receive timely feedback and adjust their video content as necessary. Furthermore, creators of videos should use social media platforms that allow for instantaneous communication between teachers and learners, such as MSN and Line.

The Connections in $5 \mathrm{C}$ require the target language to be taught alongside other disciplines, rather than being taught 
separately. However, this is a particularly demanding requirement for teachers and many professional teachers may struggle to meet this demand. It is too strict for non-professionals; therefore, it is not discussed in this paper.

Finally, to deter Chinese language learners from accessing learning resources of poor quality, online platforms such as YouTube should allow for an integrated assessment system that bans low-ranking channels from publishing Chinese teaching videos on the platform. Moreover, the Confucius Institute should enhance its marketing strategies for MOOC and enable greater access to MOOC created by the Confucius Institute by enabling its MOOC to be viewed on more websites and developing an application for mobile phones. At present, most professional Chinese teaching videos on YouTube are recordings of offline lessons. Although such videos often include extensive teaching of theory and are fairly systematic in their structure compared to other shorter videos, the number of page views and click ratio for recordings of offline lessons are much lower than shorter videos. The reason for this is that the recordings of offline lessons involve many interactive practice exercises between teachers and learners, and such content is not stimulating for long-distant learners who cannot participate. Instead, Chinese teachers should make classes more inclusive for long-distant learners by ensuring that Chinese is used as much as possible to enable sufficient input of Chinese for learners. Moreover, pinyin should be used to support learners' understanding and any use of English should be limited.

\section{B. Recommendations for Improvement for MOOC of the Confucius Institute}

By analyzing the MOOC of the Confucius Institute, Lin Liang concluded that more than half of the learners (52\%) choose the MOOC due to its relatively short length, while $52.3 \%$ of learners merely participated in lessons rather than discussing and finishing their assigned homework. From these results, it can be said that most learners were willing to learn Chinese but they did not want to spend considerable time making such efforts to learn. According to the results, $52.2 \%$ of learners learned Chinese because of their strong interest in traditional Chinese culture. Accordingly, that means the importance of enhancing the rate of cultural factors in teaching. Therefore, MOOC of Confucius Institute should reduce duration further, make sure every video is less than 10 minutes and add some cultural background knowledge in it. For the low degree of involvement, MOOC can add online real-time groups based on the current online communities and assign teachers who are at the same time zone with most learners to answer questions. According to the survey, $65.6 \%$ of learners tend to join real-time interaction, and $38.2 \%$ of learners give up communication with teachers because of different time zones. Besides, the evaluation of learners should be reduced, the learners can be divided into two parts: learners who want to get scores or diploma and learners who just want to have an overview understand of Chinese knowledge or culture, for the latter should not ask them to take part in discussions and finish homework.

\section{CONCLUSION}

Chinese is a vital carrier of Chinese heritage and tool to spread Chinese culture that has played a crucial role in expanding Chinese influence worldwide and is an indispensable part of the policy of the Belt and Road Initiative. For some students, a lack of access to professional Chinese teachers and not having the chance to travel to China to study have resulted in the Internet providing important access for learners of Chinese. However, the relatively poor levels of teaching in online classes can contribute to a loss of enthusiasm among students and can negatively affect the progress of learners. With such issues currently, it is suggested that the Confucius Institute realizes the importance of online Chinese lessons for overseas learners of Chinese. The Confucius Institute ought to use its platform as a source of knowledge for learners of Chinese language and culture to improve the opportunities for students, whether they are beginners or more advanced learners, to continue their exploration of the Chinese language and have at their disposal the necessary tools and knowledge to support their learning.

\section{REFERENCES}

[1] Everson M.\& Xiao Y. (2009). Teaching Chinese as a Foreign Language: Theories and Applications. Boston: Cheng \&Tsui Company.

[2] Liang Lin. (2016). Research on MOOC Construction for Confucius Institute (Mianxiang Kongzi Xueyuan Muke Jianshe de Yanjiu). Ph.D. Dissertation, Northeast Normal University.

[3] Mcloughlin, L. \& Lertola, J. (2014). Audiovisual Translation In Second Language Acquisition. Integration Subtitling in the Foreign Language Curriculum. The Interpreter and Translator Trainer, 1, 70-83.

[4] White, L. (2003). Second Language Acquisition and Universal Grammar. Cambridge: Cambridge University Press.

[5] Zhao Jinming. (2010). Review and Re-evaluation of the Methodology in Teaching Chinese as a Foreign Language (Duiwai Hanyu JiaoXuefa Huishi yu ZaiRenshi). Chinese Teaching in the World, 2, 243-254.

[6] Zhao Jinming. (2020). Two Research Systems of Teaching Chinese to Speakers of Other Languages__Language Teaching System and Teacher Training System (Hanyu Guoji Jiaoyu de Liangge Yanjiu Xitong-Yuyan Jiaoxue yu Shizi Peiyang). International Chinese Language Education, 5, 3-9.

Yidan Kong (b. 1989) is a PhD. student in Shanghai International Studies University. Her research interests include genre, sociolinguistics, and the Teaching of Chinese as a Foreign Language. 